\title{
Obrazowanie w kazaniach politycznych (od Skargi do Starowolskiego)
}

Patrycja Potoniec 


\section{Patrycja Potoniec}

\section{Obrazowanie w kazaniach politycznych (od Skargi do Starowolskiego)}

$\mathrm{O}$ ba terminy historycznoliterackie uzyte w tytule — „kazanic polityczne” i ,obrazowanie" - choć szeroko stosowane i uznawane za zrozumiale w sposób oczywisty, budzić mogą wątpliwości co do swego znaczenia ze wzğlędu na obszerny kompleks zjawisk przez nie nazywanych. I)otyczy to szczególnic „obrazowania”, jednak i „kizanie polityczne”, zwlaszcza z powodu mało konkretnych wyznaczników gatunkowych kazania stanowić może problem terminologiczny.

Stoumik literatury staropolskiej definiuje „kazanie” jako

tekst przenówienia wygłaszanego przez duchownego do wiernych w koścjele podczas nabożeństwa, a także pisany tekst takiej wypowiedzi'.

Zbliżoną definicję podaje Enckklopedia katolicka. okréslając je jako

formę przepowiadania kaznodziejskiego, pokrewnią homilii, mowę wyglaszaną przez kaznodzicję; niekiedy utwór literacki o walorach artystycznych ${ }^{2}$.

Obie te definicje skupiają się na kontekście, w którym ten szczególny rodzaj mowy, jakim jest kazanie, bywa wygłaszany - o odrębności kazania od innych rodzajów mów świadczyć maja: osoba mówcy (którym jest kaznodzicja) oraz czas (podczas nabozeństwa) i micjsce (w kościele), do jakich jest przypisane, a więc czynniki niezawarte w samym kazaniu, lecz wobec tego kazania zewnętrzne. Jeśli uwzględni się alternatywą formę kazania — jego pisany

' T. Szostck. Kazamie. Inaslo w: Stommik literatmry staropolskicj, red. T. Michalowska, B. Otwinowska. E. Sarnowska-Temeriusz. Wrochaw 1998, s. 366.

'A. Lewek. Kaz mia, haslo w: Enchklopedia katolickia, t. 8. Lublin 2000), kol. 1265. 
tekst - wymienianą w obu definicjach, to spośród tych trzech „wyznaczników gatunkowych" pozostanie jeden: autorem kazania (nawet zapisanego) najczęściej jest kaznodzieja. Zważywszy jednak na fakt, że to właśnic tworzenie kazań czyni ich autora kaznodzieja, i ten wyróżnik wydaje siç dośç wątpliwy. Oczywiście istnieje też co najmniej jeden wyznacznik wewnętrzny, zawarty w treści kazania: zawsze nawiązuje ono do Pisma Swiçtego - czy to wyjaśniając czytania na dany dzień (homilia), czy to omawiając kwestie moralno-religijne (kazanie tematyczne). Natomiast konstrukcja kazania nie odbiega od retorycznego wzoru mowy, a kiżda epoka uksztaltowała wlasne rodzaje kazani, ta forma wypowiedzi towarzyszy bowiem chrześcijaństwu od zarania, ściśle związana z nabożeństwami odprawianymi w Kościele. Cechą szczególną kazań w zestawieniu z innymi elementami liturgii jest to, że od początku postulowano wygłaszanie ich w językach narodowych, uznając ich szczególną funkcję edukacyjną, żcby nie rzec: popularyzatorską.

W rozwoju kazania tematycznego szczególną rolę odegrał okres renesansu, to wtedy zaczęto w kazaniach poruszać nie tylko problematykę dogmatyczno-moralną, ściśle związaną z religią, ale i zagadnienia z życia świeckiego. w tym także polityczne, do których zaliczano zarówno te związane z życiem politycznym sonst stricto, jak i kwestie społeczne czy wyznaniowe. W ten sposób uksztaltowalo siç kazanic polityczne, którego podstawowym wyróżnikiem gatunkowym jest poruszana w nim tematyka ${ }^{3}$. Za najwybitniejszego polskiego twórcę dzieł należących do tego gatunku uznaje się Piotra Skargę, okrzykniętego zarówno przez wspólczesnych, jak i potomnych jednym z najwybitniejszych kaznodziejów epoki. Stworzone przez niego pisane zbiory kazań przez wieki spotykaty siç z wielkim zainteresowaniem duchownych i świeckich, a jego Kazania sejmou'e uznano za najwybitniejsze osiągnięcie kaznodziejstwa politycznego, uznawać je więc można za wzorzec gatunkowy, punkt odniesienia dla badań nad dzielami tego typu. Ich forma jest tym cickawsza, że skladają siç one także na zwarty zespól utworów o przemyślanej kompozycji calości, którą Mirosław Korolko uznał za swoiscie hybrydyczną i określil jako dzielo na pograniczu kazania i traktatu politycznego ${ }^{+}$.

Jeszcze trudnicjszy niz "kazanie polityczne” problem terminologiczny stanowi kategoria obrazowania, czy też pokrewne jej (niekiedy uznawane za synonimiczne) pojęcia obrazı i obrazowości. Pomocą w definiowaniu może tutaj służyć teoria retoryczna (kontekst oczywisty dla rozważań nad literaturą dawną), która wyróżnia wśród figur myśli unaocznienie (eridentia), dzięki któremu ., mówca umiejscawia siebic i audytorium w pozycji naocznego świadka" Zabieg ten związany jest przede wszystkinn z funkcją molere, której podporządkowane były np. kazania polityczne. Naturalna więc wydaje się obecność maoczniania w wypowiedziach uznawanych za należące do tego gatunku:

W stylı Skargi zwraca uwagę dobór swoistej frazeologii ludowej. zwłaszcza porównań z codziennego życia gospodarskiego. Tę obrazowość i malowniczość

\footnotetext{
Por. T. Szustek. op. cit.

"M. Korolko, O prozic "Kazail sejumen'th" Piotra Skirgi. Warszawa 1971. s. 200.

'I I. Lausberge, Reror)ka literacka, tl. R. Corzkowski. Bydgoszez 2000). s. $4+2$.
} 
można thumaczyć, jak siç zdaje, charakterem odbiorców jego pism. Nie ulega przecież wątpliwości, że glównym adresatem kazani Skarghi było środowisko szlacheckie, do którego bardziej przemawialy porównania z życia zmystowego niz subtelne metonimie czy synekdochy Kochanowskiegot".

Tęopinię̧ M. Korolki z powodzeniem uda się zastosować nie tylko do porównań ze sfery zycia gospodarskiego, lecz także spolecznego i politycznego, znanego szlachcie. W Kazaniach scjmon'y'ch moźna wskazać trzy kręgi tematyczne, z których Skarga czerpal materiał obrazowania:

1. Krąg pierwszy tworzą obrazy, na które zwrócil uwage Miroslaw Korolko: bezpośrednio związane z .powszedıim” życiem na folwarku, najprawdopodobnicj znane każdemu szlachcicowi z wlasnego doświadczenia:

Bo gdy bojaźń Boża ginic i wstyd upada, w samej tylo karności urzędowej nadzieja na polnamowanie zlości zostaje. Której gdy nic nuasz, Rzeczpospolita ginie, ajakogdy obręczy z beczki opadają a nikt ich nie pobija, wszystkasig rozsypujc?.

Kupe różnych kamieni nazbierają: to wielkie, to male, to oknaggłe, to graniste, to dlugie, i zda się szpetna, pomieszana gromada. Lecz gdy mularz ocieszywajac, kamiení pięknie na kamieniu położy, piçkna się ściana uczyni. Tak i w Rzeczypospolitej uchylanim się jeden drugiemm czyni się pię̧kna zgoda i jedno ciało; i ona się nierówność poddanością gładzi i nuiarkujex.

Nawiązując do stery indywidualnych doświadczeń, ksztaltowane wyobrazenna czyni Skarga szczególnie bliskimi odbiorcy, niczym plotki z najblizszej okolicy, wiadomości typu „co 1 mnie stychać”. Uczynienie kazania swojskim zwiększal w naturalny sposób sitę przekonywania wypowiedzi. Jednoczesne nawiązanic do metaforyki biblijnej (na przyklad do przypowieści o kamieniu wçgielnym) uwzniośla „przyziemne” obrazy, pokazuje lączność między codziennym doświadczeniem a rzeczywistością biblijną, co niewątpliwie mieści się w obrębie misji ewangelizacyjnej, jaka miał do wypełnienia kaznodzieja.

2. Na krąg drugi skladają siç obrazy, w których pojawiaja się odwołania do tego, czego szlachcic zaznawal poza granicami swego folwarku, do życia spolecznego, z przewagą spotkań sejmikowych i sejmowych:

Niech się ukarząci nienczciwi i wszeteczni takim przykładem, którzy na sejniki jeżdząc zbrojno. w kościołach nie tylo po oltarzach depca, ale tez przed oltarzmi krew rozlewają i zabijạa, króla w poslach jego, i Pana Boga w kościo-

\footnotetext{
${ }^{\text {}}$ M. Korolko. IIstep do: 1. Skarga. Kazamia scinone, opr.]. Tazbr. M. Korolko. Wroclaw 1972 (BN170). s. 46.

'P. Skarga, Kuzania scimour', op', cit.. s. 11.

${ }^{x}$ Ibidem, s. 70 .
} 
lach jego lzạc. [...] O ziemia, która to cierpisz, jako pożerać będziesz obywatele swoje tak niezhożnc!'

Cóż będzie po waszych sejmach, które tylo samy na oddalenie i leczenie przygód i złych razów RP wam zostaly, jeśli z różnymi wiatry i niestwonymi myślanii na nie zjedziecie? Doznaliście i tego roku, co wam i ojczyźnie milej pomogły. I owszem, sejmy, które wam byly lekarstwem na wszystkie RP choroby, w jad siç wam obrócily. Bo na nich więcej niezgód i odrażenia myśli jeden od drugiego i stanu od stanu przyczyniacie. Na nich się buntowania i sedycyje rodzą. Z nich z więtszym rozwaśnienicm wyjeżdżacie, niźli przyjeżdzacie. I tak sejmy, na ukrzepczenic zgody i miłości spólnej braterskiej uczynione, na zapalenie rozterków shuzą".

Naturalnie przywoływanic takich wlaśnic obrazów wiąże się z tematyką samych kazań zachowanie szlachty na sejmach i sejmikach bylo wszak obiektem krytykı Skargi. Przywolane przykłady świadcząjednak, że ganiąc nie był goloslowny, odwoływal się do faktów znanych odbiorcom, jeśli nie z doświadczenia, to przynajmmiej z relacji poselskich lub plotek. Umożliwiato to identyfikację z grupą. Przywolanie wszystkim znanych faktów z życia społecznego pozwalało rozszerzyć pole obrazowania o sytuacje spoteczne, wytwarzając zarazem poczucie swojskości podobne do tego, jakie uzyskiwane bylo za pomoca obrazów odwołujących się do życia gospodarskicgo, poczucie tego, „co u muic słychac”, bylo rozszerzane do tego „co stychać u uas”. Znatury rzéczy wynika, że obrazy te są zdynamizowane, a ich namacalność wynika nié z odwołan do sfèry rzeczy, lecz z przywołania faktycznic zaistniatych lub typowych sytuacji.

3. Do kręgu trzeciego zaliczyć należy te obrazy, które odnoszą się do wydarzeri rozgrywających się poza granicami Polski, zarówno aktıahnych, jak i przeszłych, zgodnie z nieściśle przytoczoną przez Skargę myślą Grzegorza z Nazjanzu:

Zacna rzecz jest mieć rozum pelny wiadomością historyi, bo historia jest mądrość w kupę zlożona i rozun ludzi wiela w jedno zebrany".

Oczywiście przykłady zaczerpnięte ,z zcwnątrz" zawsze były przytaczane przez Skargę w ten sposób, by nawiązać do wydarzeń w Rzeczypospolitej:

Patrzcie na upadki królestw, które od Kościoła ś. odpadty, jako opustoszały! Patrzcie na bliską sąsiedzką ziennię Węgrów, niegdy bogatych i możnych! Na ono zlote jabłko królestwa ich, jako na obleciały dom, jako na dąb, z którego liście opadly, jako na ogród uschly bez wody, jako na kuczkę przy winnicy ${ }^{12}$.

\footnotetext{
"Ibidem. s. 93.

"Ibidem, s. 6t 65. Wh przypisic J. Tazbir podkreśla. ze Skarga nawiązuje do wydarzenia faktycznego, jakin bylo rozejście się sejmu 1597 rokı bez powziçcia uicluwal.

${ }^{11}$ Ibidem. s. 26.

12 Bbidem. s. 100).
} 
Zwraca uwagę znaczna ogólność, szkicowośc tego stowem malowanego obrazu w odniesicniu do spraw państw obcych, w tym wypadku Węgier, których upadck mial stanowić groźne memento dla szlachty polskicj. Szkicowość tę thumaczyć można poczuciem dystansu geograficznego, lecz i mentalnego, jakic wytwarzalo przywolanic przykładu z zewnątrz. To, co dotyczy obcych, zawsze jest muiej przckonujące, niechę tnie korzystany z cudzego doświadczenia. Zresztą celem mówcy było zwrócenie uwagi na sytuację w Polsce, pouczający i odstraszający przyklad mógt poruszyć odbiorcę tylko przez chwilę. Zanim nastąpilo uspokojenie na zasadzie „niech na świecie wojna, byle nasza wiés spokojna”, autor Kazań sejmou'ych juz przenosil uwagę odbiorcy na rodzinny grunt: przedstawiając obraz opustoszalego królestwa węgierskiego, powracal do obrazowania z najblizszego kręgu doświadczenia - uschły ogród, drzewo bez liści. Przekonują one konkretem, silnym zakorzenieniem w rzeczywistości, przy jednoczesnym sugestywnym nawiązaniu do metaforyki biblijnej.

Jak pokazują powyższe przykłady, Skarga znajdowal źródło dla swych obrazów w różnych sterach życia, zawsze jednak staral się pozostać na plaszczyźnie znanej odbiorcy i zrozumialej dla niego. Należy podziwiać bogactwo obrazowania w Kazaniad scjmon'ydi obfite urozmaicanie toku wywodu obrazami o nanacalnym wręcz realizmie ulatwić zapewne miało prezentaçę idei dość abstrakcyjnych (analiza ustroju państwa), a przy tym niepopularnych w środowisku szlacheckim (wzmocnienie whadzy monarszej). Tworzyło poczucie bliskości pomiędzy mówcą a odbiorcą, budowane na wspólnocic codziennego doświadczenia.

Dzięki swym nieprzeciętnym zdolnościom Skirga został uznany za najwybitniejszego twórcę okresu rozkwitu kazania politycznego w Polsce - schylku XVI wieku' ${ }^{13}$. I choć nigdy potem gatunck ten nie wspiąh siç na takie wyżyny jak za czasów Skargi, jednak ,pierwiastek polityczny czy ściślej: patriotyczny — przcniknie prawie całą literaturę kaznodziejską baroku" " Czy siedemnastowieczni kaznodzieje posłıgiwali siç równie rozbudowanym obrazowaniem jak autor Kazan sejmonych? Wśród kaznodziejów katolickich aktywnych w pierwszej polowie XVIJ wicku wymienia się przede wszystkim Fabiana Birkowskiego i Szymona Starowolskiego (w nim szczególnie upatrując spadkobiercy tradycji Skargowskiej) ${ }^{15}$; zaden z nich nie napisal dzieła w calej petni podobnego do Kazan scjmon'ych (traktatu politycznego zlożonego z mogacych funkcjonować samoistnie kazaí), jednak obaj tworzyli kazania polityczne. Skupiali się w nich bardziej na kwestiach religijnych i wyznaniowych (zwlaszcza Birkowski), tym bardzicj, że wydarzenia polityczne pierwszej polowy wieku, spowodowaly odejście od radykalnych projektów reformy ustrojowej, a takze sklonily duchowieństwo do bardziej oględnego poruszania problenów organizacji panistwa".

Również w zakresie obrazowania kaznodzieje stali się bardziej powściągliwi. Birkowski i Starowolski o wiele rzadziej niz Skarga odwolujį̧ się do doświadczeń życia codziennego, a te

\footnotetext{
"Por. M. Korolko. O prozic"Kizilli scjmon'yd".... op. cit.

14 Ibidem, s. 203.

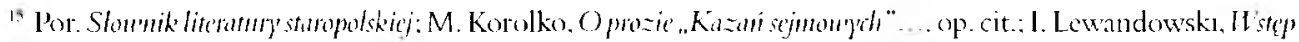
do: Sz. Starowolski. Il ber z pism. Wroclaw 19)1 (BN I 272).

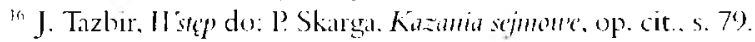


nicliczne pojawiające siç odwolania należą do skonwencjonalizowanego raczej zestawı chwytów:

Whasne żaby, które faraona karały, co dzién tu w Warszawie krzekotają przeciwko prawdzie chrześcijańskiej, ale pokarmu zadnego rozumowi nie podadzą [...]. I śmieciez dokuczać stanowi duchownemu prosząc go, aby te żaby wasze krzekotały tu w Polszcze tak bezpiecznic jako w jeziorach genewskich? ${ }^{17}$

Metafora ta, zaczerpnięta z kazania Birkowskiego, a oparta na oczywistym nawiązaniu biblijnym, odbiega jednak od Skargowych obrazów. Wynika to naturalnie z różnic miçdzy porównaniem (na któryn oparte jest $w$ znaczncj części obrazowanic w Kazaniach sejmon'y'h) a metaforą, lecz także wiąże siç z tym, że akcent nie jest położony na wyrazistości, „namacalności” obrazu „krzekoczących” żab, perswazja opiera się tu głównie na prześniewczej nocy równania: innowierca = nic nieznaczący plaz. Należy jednak podkreślić, że obaj kaznodzieje nie odwoluja się raczej do doświadczeń dnia codziennego, poprzestają w tym względzie na ogólnikowych i mało wyrazistych nawiązaniach.

Nie można jednak w calości odnieść tych uwagg do obrazów zaczerpniętych ze stery doświadczeń związanych z życiem społecznym - zarówno u Birkowskiego, jak i u Starowolskiego pojawiają się one dość często i ukazuja, podobunic jak u Skargi, szlacheccką niezgodę:

Dla Boga, co się dzieje, czemu się nie możem oprzeć nieprzyjacielowi, czemuśmy tak pobledli od strachu, hubo jeszcze daleko jest od nas? Czemu nie myślimy o sobie, czemu się nie zgromad zimy do kupy, abyśmy radzili o ojczyźnie, ale jeden tam, drugi sam uciekany, a drudzy poddają się nieprzyjacielowi i od niego zołd biora, aby pustoszyli jeden drugiego ? $^{1 \times}$

Obraz ten, skonstruowany za pomocą pytań retorycznych, w sposób podobny jak u Skargi nawiązuje luźno do faktycznych wydarzeń, tworząc dzięki nim nogólnienie, mówiące o niezgodzie, lecz nie brak mu szczególów, jakimi przykuwał uwagę Skarga. Pod tym względem Birkowski jest bardziej wymowny, choć przyjmuje inną perspektywc̨:

Przypadal często świçtej pamięci król Zyğmunt III na tę śmiertelność królestw, z rozumem swoim trzymal dwoje królestw: polskic i szwedzkic, nad obiema pański gniew i miecz dobyty z nicha był spuszczony. A cóz innego są wojny, jedno miecze boże, któremi znosi Bóg narody wszystkic? Gdy rokosze i rebelie, i konfederacje widywal, lubo to w Polsce, lubo we Szwecyi, krzyczal z prorokiem: „O mieczu Pański, pokiz nie spoczniesz? Wnidź kiedy do pochew twoich, ochlodni, umilkni!". On tego domawia, a do niego glos z nieba: ,Jakoż ma spoczywać, ponieważ mı Pan rozkazal przeciwko Askalonowi (Polsce

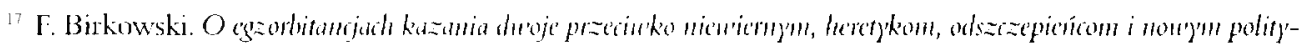
kom!. wyd. J. K. Turowskı, Kraków 1859. s. 8-9.

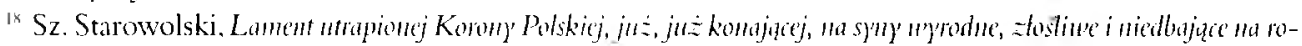
dzicielke sumol. wyd. J. K. Turowski. Kraków 1859. s. 12.
} 
i Szwecyi) i przeciwko pomorskim krainom jego, i tam go sobie nająl?". Nic wszystkic królestwa mieczem powstają, ale niemal wszystkie od miecza giną".

Jest to obraz bardzo rozbudowany, zawierający elementy fabularne, co zwiększa jego atrakcyjność, a więc tym bardziej przykuwa nwagę, zwłaszcza ze kaznodzieja wprowadzil wątek nadprzyrodzony: Bóg przemawia bezpośrednio do króla. I ość znacznie oddala się to jednak od doświadczenia odbiorcy, krytyce podlegają tu zachowania szlachty, jednak pozostają one na dalszym planie, na plan pierwszy wysuwa się wojna jako kara, a także, w związku z. tematem kazania, postać króla pogrążonego w żalı z powodı „domowej niezgody”. Obraz ten nie ujmuje realizmem, lecz raczcj patetycznym tonem mistycznym, mimo silnego zakorzenienia w faktycznych wydarzeniach.

Największe podobicństwo do obrazowani: Skargi ujawnia się u Starowolskiego w obrazach dotyczących wydarzeń rozgrywających się poza granicami Polski:

W Czechach, Sląskı i Morawic podobno tylko w majętnościach niewolę cierpia. że je im szacują i Szwedowi, i cesarscy żołnierze. Ale u nas w wolnynn narodzic, w whasnyn zdrowiu nicwolę cierpią, w żonach, synach, córkach i w shıgach. O co gdy się ubogi człowiek do prawa pospolitego uciecze, zaraz mu mówią: "Nie dla was to piszą statuty, smerdowie, ale dla panów”-1!.

Poza podobieństwem tematycznym - nawiązaniem do upadku Węgier, które nie jest istotne dla problemu obrazowania — podobieństwo przejawia się w szkicowym ledwie zarysie wydarzeń w obcym kraju i natychmiastowym skierowaniu tematu na grunt znany. Wlaściwy obraz to scenka rodzajowa z polskiegro sądu, sytuacja na Węgrzech jest tylko dalekim punktem odniesienia, wykorzystanym w sposób przewrotny.

Przywołane powyżej, mało przekonujące. lecz najlepsze, jakie można było znaleźć w obrębie dostęppnych źródeł. przykłady obrazowania w twórczości Birkowskiego i Starowolskiego wskazują, ze nie kontynuowali oni tradycji Skargowego barwnego, sugestywnego unaoczniania. Dlaczego tak się stało, skoro uznaje się mistrzostwo Skargi jako autora kazań politycznych, a wymienionych mlodszych kaznodzicjów wskazuje jakojego spadkobierców? Czyjest to problem odmicnuości stylu autorskiego? Nie wydaje się to możliwe, skoro nieco mlodszy od Skargi Hieronim Powodowski w wydanej dwa lata przed Kazaniami sejmon'ymi Propozycji stosuje obrazowanic zbliżone do Skargowego:

1. Krąg pierwszy - Powodowski także sięga do porównan z życia gospodarskiego:

Jako ptastwa gospodarstwu szkodliwego do tyla zbywany plaszanien, straszydlami, sidlani i zbieraniem z gniazda, az gdy to nie pomoze, i sane gniazda ich rozmiatamy, takżeć krześciaństwo, a zwlaszcza nasza Polska, iż nic przesta-

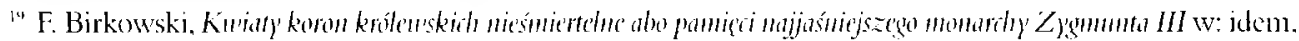
Kizania plajedec i pugradoue, wyd. J. K. Turowski. Krakow 1859. s. 97.

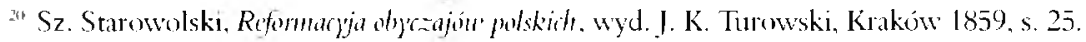


wa winnicy boskicj dawncj wiary szczepicnia szkodzić, za rozmaitymi plagami dotąd przepuszczanymi, tedy Pan Bóg podobno na to zalożyl, aby (jako grozi przez proroka) i gniazdo nasze do końca spustoszy ${ }^{21}$.

W ten sam sposób jak Skarga Powodowski przemawia do szlaclity, odwołując siç do ich doświadczeń jako gospodarzy folwarcznych, wskazuje konkretne, wszystkim znane sytuacje z życia codziennego jako punkt odniesienia.

2. Krag drugi - zycie spoleczne:
A u sądów wiçc, Boze, co ty policzków pocierpisz, gdyz juz pospolicie przysięgę zal igrzysko sobie maja. Więc co gorsza mako sani pryncypałowie nają na takim Boga policzkowaniu, jeszcze (jako ono u Piłata całą rotę katów) wielkie koło drugich do tego przynajmują, którzy dalcko siç zrodziwszy. nic wiedząc ani czasem chą̧ wiedziéc o co, na ksztalt juz nie ludzi, ale sanych Szatanów, Boga, miasto pochwalenia, ztorzeczą. Ale więc najgorsza, iz urzędy wiedząc i widząc to, dopuszczają tego i za sprawiedliwość przyjmują.

Tematycznie obraz ten nawiązuje także do wskazywanych przez Skargę bolączek życia spolecznego Rzeczypospolitej ${ }^{n 2}$, charakteryzuje się podobnym do Skargowego realizmem w kreśleniu obrazka obyczajowego, nawiązującego do doświadczeń znanych wielu ze szlachty.

3. Krag trzeci - wydarzenia poza granicami Polski:

Toż [podbój turecki - P. P.] się stało Dalmacyjej, Sklawoniej, Illyrykowi i inszym odleglym micjscam i narodom. Dokąd Węgierska ziçmia wiarę katolicką statecznic trzymala, a osobliwą patronkę i obrońcę Matkę Bożą, i w pospolitej mincy swej wyznawala, choć w gę̧bie prawie tureckiej, jednak mocnym murem od nich wszemu chrześciaństwu była. [ . . J Jako się tam jednak wdarły sekty czeskie i niemieckie, włozyl tam Turek nogę i ona ziemia stała się gniazdem wojny tego poganistwa z chrześcijaństwem. Gdy potym przeklęte ariaństwo i nowokrzczeństwo tam kosz swój zalożyło, z którego jakoby zagonani rozpuszczonemi prawdę chırześcijańską na wsze strony wojowato, począl tyran turecki gớrę brać. [...] nie dziw, iż Pan Bóg na ten ostatek rękę poganiską rozciąga, a chrzéscijańska jakoś skurcza ${ }^{23}$.

Powodowski duzo bardziej niż Skarga rozbudował obraz upadku krajów obcych, jednak i on staral siç nadać rys swojskości przedstawianemu obrazowi, dążąc do ukazania plaszczy-

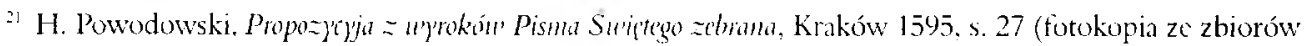
Pracowni Slownika l'olszczyzny XVI Wicku IBL PAN w Toruniu, na podstawic starodrukuze zhiorów Bibliozteki Kónnickicj PAN, sygn. Q"2+25).

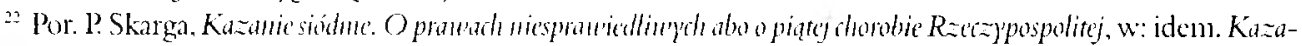
mia sejmowe, op. cit.

11. Powodowski, Propozyja.... s. 33.
} 
zny wspólnej dla znajdujących się w niewoli krajów obcych i Polski - tym, co je łączy, jest upadiajcy (w mniemaniu kazıodziei) katolicyzm. Przykladem Węgier i iunych krajów poshıżyl się Powodowski bezpośrednio - ich los w danym momencie ukazując jako moźliwą przyszlóść Polski, jeśli jej obywatele nadal będą porzucać katolicyzm.

Jak widać bogate, nawiązujące do różnych sfer życia, ale przede wszystkim odwołują̧ce się do codziemnego doświadczenia odbiorcy obrazowanie nie jest cecha indywidualna stylu Skargi. Miroslaw Korolko obrazowość jego stylu uznał za ważny czynnik perswazyjny, dostosowany do mentalności odbiorcy. Czy można wnioskować, że to montalność odbiorcy szlachty polskiej - uległa takim zmianom przez niecale pięćdziesiąt lat na przełomie wieków XVI i XVII? Jest to hardzo wątpliwe, na ogól raczej podkreśla się petryfikację poglądów szlachty w tym okresie, poglębianie się kultu dla żywota wiejskicgo, a więc wrastanie w kulturę agrarną, nawet wbrew coraz bardziej niespokojncj sytuacji międzynarodowcj ${ }^{2+}$. Niè moźna także powiedzieć, żeby kazania Birkowskiego i Starowolskiego były skicrowanc do innego odbiorcy niz kazania Skargi czy Powodowskiego.

Czy w takim razie o zarzuceniu obrazowania tak konkretnego, nawiązującego do powszedniego doświadczenia mogło zadecydować deconm? Czy uznano je za niestosowne dla stylu wysokicgo, jakim powinno siç charakteryzować kazanic? I to wydaje siç mało prawdopodobne - „przyziemne” obrazy Skargi były mocno zakorzenione w metaforyce biblijncj, przede wszystkinn ewangelicznej, szczególnic cenionej i najstosownicjszej w kazaniach. Oczywiście o ograniczeniu sfery obrazowania zadecydować mógł także niedostatek talentu twórców, jednak zarówno Birkowski, jak i Starowolski poslugiwali siç z duzą bicgłością innymi, o wicle trudniejszymi w użyciu, figurami myśli, mało więc prawdopodobne, aby nie podołali sztuce unaoczniania. Nic slużyło to także upraszczaniu toku wywodu, rezygnacja z odwolań do konkretu codzienności czynila kazanie bardziej abstrakcyjnym, a więc zapewne trudniejszym w odbiorze. Możua przyjąc, że odbiorca szlachecki, wyksztalcony w sztuce oratorskicj potrafił docenić kunszt kaznodziei, jednak nie wydaje się, żeby kazanie o ograniczonym obrazowaniu było bardziej atrakcyjne niz inkrustowane przemawiającymi do wyobraźni obrazami.

Być moze przyczyny takiego stanu rzeczy nie należy się̧ dopatrywać w ograniczeniach twórców, a raczej gatunku? Jak to już zostalo powiedzianc na wstępie, zå szczy towy moment jego rozwoju uznaje się koniec XVI wicku, a więc okres, kiedy tworzyli Skarga i Powodowski. Można więc przyjąć, ze zmnicjszenie roli obrazowania w kazaniach politycznych stanowi wyraz ewolucji (być może degradacji) gatunku, który szczytowy moment rozwoju miat juz za sobą i z upływeu czasu zmieniał się, a jego realizacje ograniczaly się do uwzględnienia jego cech podstawowych, takich jak tematyka polityczno-spoleczna i nawiązania biblijne.

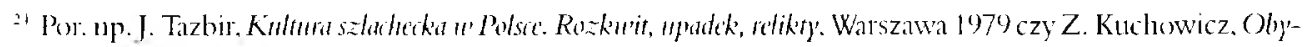
ciuje staropolskic SI II i XI II wiekn, Lódź 1975.
} 